\title{
IAMJ
}

INTERNATIONAL

AYURVEDIC

MEDICAL JOURNAL

\section{ROLE OF HOLISTIC APPROACH IN THE MANAGEMENT OF ULCERATIVE COLITIS W.S.R. TO RAKTATISARA - A CASE STUDY}

\author{
Katarmal Durga Harishbhai ${ }^{1}$, P. Hemantha Kumar ${ }^{2}$ \\ ${ }^{1} \mathrm{Ph} . \mathrm{D}$. Scholar, ${ }^{2}$ Professor \& Head of Department; \\ P.G. Dept. of Shalya Tantra, National Institute of Ayurveda, Jaipur, Rajasthan, India
}

Email: bhanushalidurga256@gmail.com

\section{https://doi.org/ $10.46607 /$ iamjp04042020}

(Published online: May 2020)

Open Access

(C) International Ayurvedic Medical Journal, India 2020

Article Received: 02/04/2020 - Peer Reviewed: 07/05/2020 - Accepted for Publication: 07/05/2020

\section{Check for updates}

\begin{abstract}
Ulcerative colitis is chronic inflammatory bowel condition which is increasing in prevalence in modern era particularly in age group of 20 to 40years. The exact cause of this disease is unknown yet. Symptoms of UC are altered bowel habits, increased frequency of defecation, bleeding per rectum, mucus mixed stool and tenesmus etc. Associated symptoms are weight loss, weakness, fatigue etc. On the basis of these features UC can be compared with Rakta atisaar. UC is disease of nature with in between symptom free periods. In contemporary science there is no curative treatment for UC. Symptomatic relief is provided with steroidal drugs and drugs like salphasalazine. So, this is need of hour that a protocol should be designed to provide relief to patient suffering from this disease. Present case study focuses on holistic approach towards entity under consideration rather than single formulation of therapy as the disease deteriorates physical and mental wellbeing of patient. A three months of treatment with proper lifestyle led to complete relief in symptoms.
\end{abstract}

Keywords: Ulcerative colitis, Rakta atisaar, inflammatory bowel disease

\section{INTRODUCTION}

Ulcerative colitis (UC) is included in chronic inflammatory bowel diseases (IBD). The other condition under inflammatory bowel diseases is Crohn's disease (CD). The two entities can be differentiated by colonoscopic examination in which UC affects mostly anal canal and rectum whereas $\mathrm{CD}$ can affect any part of gastrointestinal tract. Symptoms of UC are altered bowel habits, increased frequency of defecation, 
bleeding per rectum, mucus mixed stool and tenesmus etc. Associated symptoms are weight loss, weakness, fatigue etc. On the basis of these features UC can be compared with Rakta atisaar. ${ }^{1}$

Incidence Increasing incidence of IBD can be attributed to lifestyle changes and dietary habits. The age of manifestation is mostly $20-40$ yrs. The disease is more prevalent in urban population. There is no definite theory available till date in concern to causes and pathogenesis of IBD.

Possible causes of IBD are - Genetic, Defective immune regulation, Stress, Poor digestion, Poor nutrition, Colon infections

In contemporary science there is no curative treatment for UC. Symptomatic relief is provided with steroidal drugs and drugs like salphasalazine. Review of literature reveals that Rakta atisaar is disease of Purishvaha Srotasa. It is Tridoshaja disease with Pitta predominance. Sign and symptoms of ulcerative colitis can be co-related with Rakta-Atisaar. Sushruta has described Rakta Atisaar as advanced stage of Paittik Atisaar. Its symptoms like Shulam, Vidaaham, Gudpaaka, RaktaPravritti can be compared with rectal pain, inflammation, rectal ulceration and bleeding of ulcerative colitis. $^{2}$

\section{Etiopathogenesis}

The root cause of all diseases is said to be Agnimandya which occurs due to faulty dietary habits as well as lifestyle habits. Excessive consumption of Pittaja - Ahara (Pitta aggravating foods) and Pitta aggravating regimen leads to vitiation of Pitta Dosha which further cause the vitiation of Rakta Dhatu. Improper digestion leads to Agnimandya and Vata Kapha also deteriorates. This Tridosha-dushti with Pitta predominance and involvement of Rakta Dhatu leads to manifestation of symptoms such as increased frequency of defecation, mucus mixed stool, bleeding per rectum. The chronicity of the condition shows its effect on general wellbeing of the patient in terms of malnutrition, weakness, fatigue, irritability and confusion. This progresses further if patient continues with the same type of food habits leading to inflammatory changes in rectum and colon. Ayurveda aims at modification of lifestyle, use of herbal formulations and Panchkarma therapy as management of entity under consideration.

\begin{tabular}{|c|c|c|c|c|c|c|}
\hline Si.No & Drug & Rasa & Virya & Vipaka & Guna & Action \\
\hline 1. & Bilva (Aegle marmelos) & $\begin{array}{l}\text { Kashaya } \\
\text { Tikta }\end{array}$ & Ushna & Katu & $\begin{array}{l}\text { Laghu, } \\
\text { Ruksha }\end{array}$ & $\begin{array}{l}\text { Grahi, Agnivardhak, Kaphanashaka, Antra- } \\
\text { Balkaraka }\end{array}$ \\
\hline 2. & Surasa (Ocimum sanctum) & $\begin{array}{l}\text { Katu, } \\
\text { Tikta }\end{array}$ & Ushna & Katu & $\begin{array}{l}\text { Laghu, } \\
\text { Ruksha }\end{array}$ & $\begin{array}{l}\text { Vatakaphahara, Agnideepana, Stambhana, } \\
\text { Krimihara }\end{array}$ \\
\hline 3. & $\begin{array}{l}\text { Karanja } \\
\text { (Pongamina pinnata) }\end{array}$ & $\begin{array}{l}\text { Tikta, Katu, } \\
\text { Kashaya }\end{array}$ & Ushna & Katu & $\begin{array}{l}\text { Laghu, } \\
\text { Teekshna }\end{array}$ & Kaphavatahara, Krimighna, Pachana \\
\hline 4. & $\begin{array}{l}\text { Tagar (Valeriana } \\
\text { wallichhi) }\end{array}$ & Kashaya, Katu & Ushna & Katu & $\begin{array}{l}\text { Laghu, } \\
\text { Snigdha }\end{array}$ & $\begin{array}{l}\text { Vatakaphahara, Vishahara, Amapachana, Ma- } \\
\text { nasarogahara, Nidrakara }\end{array}$ \\
\hline 5. & $\begin{array}{l}\text { Surahva } \\
\text { (Cedrus deodara) }\end{array}$ & Tikta & Ushna & Katu & $\begin{array}{l}\text { Laghu, } \\
\text { Snigdha }\end{array}$ & Deepana Pachana Vatahara Vednahara \\
\hline 6. & $\begin{array}{l}\text { Nisha } \\
\text { (Curcuma longa) }\end{array}$ & Tikta,Katu & Ushna & Katu & $\begin{array}{l}\text { Laghu, } \\
\text { Ruksha }\end{array}$ & $\begin{array}{l}\text { Krimighna,Raktavikarahara, Shothahara,Ve- } \\
\text { danahara }\end{array}$ \\
\hline 7. & $\begin{array}{l}\text { Daru haridra } \\
\text { (Berberis aristata) }\end{array}$ & $\begin{array}{l}\text { Tikta,Katu, } \\
\text { Kashaya }\end{array}$ & Ushna & Katu & $\begin{array}{l}\text { Laghu, } \\
\text { Ruksha }\end{array}$ & $\begin{array}{l}\text { Deepan, Pachana, Raktashodhana, } \\
\text { Vranaropana, Kaphapittahara }\end{array}$ \\
\hline 8. & $\begin{array}{l}\text { Haritaki } \\
\text { (Terminalia chebula) }\end{array}$ & $\begin{array}{l}\text { Lavana varjya } \\
\text { kashaya rasa pra- } \\
\text { dhana pan- } \\
\text { chrasatmaka }\end{array}$ & Ushna & Madhura & $\begin{array}{l}\text { Laghu, } \\
\text { Ruksha }\end{array}$ & $\begin{array}{l}\text { Pachana, Anulomana, Sara, Shothahara,Ra- } \\
\text { sayana }\end{array}$ \\
\hline 9. & $\begin{array}{l}\text { Vibhitaki } \\
\text { (Terminalia bellerica) }\end{array}$ & Kashaya & Ushna & Madhura & $\begin{array}{l}\text { Laghu, } \\
\text { Ruksha }\end{array}$ & Kaphavatahara,Krimighna,Rasayana \\
\hline 10 & $\begin{array}{l}\text { Amalaki } \\
\text { (Emblica officinalis) }\end{array}$ & $\begin{array}{lr}\text { Lavana varjya } \\
\text { amla rasa pra- } \\
\text { dhana pan- } \\
\text { chrasatmaka }\end{array}$ & Sheeta & Madhura & $\begin{array}{l}\text { Ruksha, } \\
\text { Laghu }\end{array}$ & $\begin{array}{l}\text { Tridoshaghnarasayana, Vranaropana.Antra- } \\
\text { balya }\end{array}$ \\
\hline
\end{tabular}




\begin{tabular}{|c|c|c|c|c|c|c|}
\hline 11. & $\begin{array}{l}\text { Shunthi } \\
\text { (Zingiber officinalis) }\end{array}$ & Katu & Ushna & Madhura & $\begin{array}{l}\text { Laghu, } \\
\text { Snigdha }\end{array}$ & $\begin{array}{l}\text { Kaphavatahara, Deepan, Pachanaanuloman, } \\
\text { Amapachana }\end{array}$ \\
\hline 12. & $\begin{array}{l}\text { Maricha } \\
\text { (Piper nigrum) }\end{array}$ & Katu & Ushna & Katu & $\begin{array}{l}\text { Laghu, } \\
\text { Teekshna }\end{array}$ & $\begin{array}{l}\text { Kaphavatahara, Krimighna, Vishaghna, } \\
\text { Shulahara, Rasayana }\end{array}$ \\
\hline 13. & $\begin{array}{l}\text { Pippali } \\
\text { (Piper longum) }\end{array}$ & Katu & Anushna & madhura & $\begin{array}{l}\text { Laghu, } \\
\text { Teekshna, } \\
\text { Snigdha }\end{array}$ & $\begin{array}{l}\text { Kaphavatahara, Deepan, Pachana, Rasayana, } \\
\text { Shulprashamana }\end{array}$ \\
\hline 14. & Goat urine & $\begin{array}{l}\text { Kashaya, } \\
\text { madhura }\end{array}$ & Ushna & - & $\begin{array}{l}\text { Laghu, } \\
\text { Ruksha }\end{array}$ & Shothahara, Vishaghna \\
\hline
\end{tabular}

\section{Case Details}

A male patient of age 40 years came to Shalya Tantra OPD of National Institute of Ayurveda with the chief complaints of bleeding per rectum and pain in perianal region since 2 months. Detailed history taking revealed that patient was suffering from abdominal pain, mucus discharge per rectum since 18 years. Frequency of defecation increased over the years upto 7 to 8 times per day with recurrent episodes of diarrhea and mild fever. This led to weakness, weight loss and irritability, anxiety and insomnia. Patient was taking sulphasalazine and omnacortil since last 10 years as prescribed by

Contents of Bilvadi gutika ${ }^{3}$

Contents of Kutaj ghan vati ${ }^{4}$

\begin{tabular}{|l|l|l|l|l|l|l|}
\hline Sr.no & Drug & Rasa & Virya & Vipaka & Guna & Action \\
\hline 1. & $\begin{array}{l}\text { Kutaj (Holarrhena } \\
\text { antidysentrica) }\end{array}$ & $\begin{array}{l}\text { Kashaya } \\
\text { Tikta }\end{array}$ & Sheeta & Katu & $\begin{array}{l}\text { Laghu } \\
\text { Ruksha }\end{array}$ & $\begin{array}{l}\text { Shleshmapittahara, raktahara, samgrahika, Upashoshana, } \\
\text { Deepana, Pachana, atisarhara, krumihara }\end{array}$ \\
\hline 2. & $\begin{array}{l}\text { Ativisha (Aconitum } \\
\text { heterophyllum) }\end{array}$ & $\begin{array}{l}\text { Katu, } \\
\text { Tikta }\end{array}$ & Ushna & Katu & $\begin{array}{l}\text { Laghu } \\
\text { Ruksha }\end{array}$ & $\begin{array}{l}\text { Shleshmapittahara, Deepana, Pachana, atisarhara, krumi- } \\
\text { hara, amahara }\end{array}$ \\
\hline
\end{tabular}

2. Shirodhara ${ }^{5}$ with Takra by standard protocol for 1 month.

3. Meditation ${ }^{6}$ for 30 minutes daily.

4. Vajrasan 10 minutes three times a day

Duration of treatment: 3 months

Pathya - Apathya: Patient was advised to avoid spicy, sour, pungent food, nonveg, smoking, alcohol, daytime sleep, exertional activities.

Observation and result

Patient got complete relief in sign and symptoms with frequency of defecation 2 times per day within three months of treatment. After 3 months medicines were stopped, and patient was advised to include meditation and Vajrasana in routine lifestyle. One year follow up was taken via telephonic conversation and patient did not suffer any remission of symptoms. gastroenterologist. Routine investigations were within normal limit except ESR which was $35 \mathrm{~mm} / \mathrm{hr}$ indicative of chronic inflammatory changes. Colonoscopic

\section{Types of intervention}

Oral medication, Panchkarma - Shirodhara, Meditation, Asana

1. Oral medications were given for 3 months

Bilvadi Gutika 500 mg BD, Kutaj Ghan Vati 500 mg $\mathrm{BD}$ findings were suggestive of Ulcerative colitis.

\section{DISCUSSION}

Ulcerative colitis is inflammatory condition of bowel for which no definitive cause has been established till date by contemporary science. It can be co-related with Rakta Atisaar described by Acharya Sushruta as adthe age group of 20-40 years. Considering Dosha Dushti description, Rakta Atisaar occurs due to Tridosha Dushti with Pitta predominance, so the treatment plan was aimed at pacification of Tridosha.

Effect of interventions

Oral Medications: Agnideepana, Amapachana action nimandya). This further leads to proper digestion. Contents of Bilvadi Gutika has Vranaropana (healing property) as well as Antrabalya (Strengthening property) vanced stage of Pittaj Atisaar. Disease is prevalent in of Bilvadi Gutika acts on impaired digestive fire ( $A g$ - 
action which helps in repair of damaged mucosal layer. Stambhana action of Bilvadi Gutika and Kutaj ghan vati is helpful in reducing the frequency of defecation as well as cessation of bleeding.

Panchkarma: Shirodhara was done with Takra with the purpose of pacification of Vata and Pitta Dosha which acted on insomnia and at the end of one month of Shirodhara treatment patient was habituated to sleep for 7 hours.

Meditation: It was advised to relieve irritability, anxiety. Vajrasaana: It helps in pacification of Saman Vayu and Pachak Pitta which leads to improvement in digestive function of intestine. This case study is proof of the fact that few chronic diseases requires individualistic approach rather than generalized approach.

\section{CONCLUSION}

Holistic approach of Ayurveda is capable of providing cure for IBD. This case study yielded encouraging results paving the way for development of management protocol for IBD after a clinical study on large sample size.

\section{REFERENCES}

1. Acharya Vidyadhar Shukla, Pof. Ravi Dutt Tripathi, Atisarachikitsa, Charaksamhita. Vol-2, Chaukambha Sanskrit Pratish- than, Varanasi, Reprint-2007, p.477.

2. Vijeyta Singh, Alok kumar Srivastav. An ayurvedic approach in the management of ulcerative colitis. International Ayurvedic Medical Journal. Volume 2; Issue 6; November- December - 2014

3. Paradkar. Pandith. Hari Sadashiv Shastri. Astanga Hrudayam. Reprint: Chaukhamba Surabharati Prakashan. 2014. Uttarasthan 36/193. p. 956.

4. Vaidhya Vishnu Acharya, Siddha Yoga Sangraha, 8th edition, p. 24.

5. Uebaba K, Xu FH, Tagawa M., et al Using a healing robot for the scientific study of shirodhara, Med. Biol Mag.2005; 24(2): p. 69-78 [Pubmed].

6. Jevning R, Wallace RK, Beidebach M. The physiology of meditation: A review. A wakeful hypometabolic integrated response. Neurosci Biobehav Rev.1992; 16: $415-$ 24
7. Dr. Vikrant thakur, Dr. Vikash Bhatnagar. Vajrasana and its physioanatomical aspect. International Ayurvedic Medical Journal. Volume 4; Issue 7; July-2016.

\section{Source of Support: Nil Conflict of Interest: None Declared}

How to cite this URL: Katarmal Durga Harishbhai \& P. Hemantha Kumar: Role Of Holistic Approach In The Management Of Ulcerative Colitis W.S.R. To Raktatisara A Case Study . International Ayurvedic Medical Journal \{online\} 2020 cited May, 2020\} Available from: http://www.iami.in/posts/images/upload/2353 2356.pdf 